\title{
Lifeworld-Oriented Family Support
}

\author{
Špela RaZPotniK ${ }^{\star 1}$, Nada TurnšeK ${ }^{2}$, Jana Rapuš Pavel ${ }^{3}$ AND \\ Olga POLJŠAK ŠKraban ${ }^{4}$
}

$\approx$ Since the spring of 2014, the authors of this article, joined by a wider group of students, have been dedicated to researching vulnerable families and their involvement with education systems. In the initial phase, we explored the experiences and challenges that these families face and how they understand and address these challenges. Next, we were interested in the forms of support that these families receive, how the network of educational and social welfare services responds to their needs, and the quality of their cooperation. We found that both the families and the expert services experience dissatisfaction when it comes to their cooperation: families often feel that they are being sent from one door to another with their problems, which remain unaddressed, while expert services feel that they cannot cope with the problems of vulnerable families, problems that they view as insoluble. Our pivotal finding is therefore that it is vital to develop more flexible and consistent forms of support that respond to the concerns and challenges of the daily lives of vulnerable families (Razpotnik et al. 2015).

In the action research reported on in the present article, we have focused on investigating the development of a newly emerging flexible and comprehensive form of family support that was co-initiated by ourselves (the researchers) and primarily implemented by volunteers and NGO workers. The main characteristics of this support are flexibility, presence in the daily lives of the family, building a cooperative relationship, and prioritising the dynamics and needs of the family rather than the formal demands of organisations and institutions. The article delineates the emerging approach of lifeworld-oriented support, which is implemented and reported on first and foremost by the volunteers involved. Lifeworld-oriented support is a supplementary addition to conventional forms of family support, represented and reported on predominantly by representatives of educational and social welfare organisations.

Keywords: vulnerable families, social pedagogy, lifeworld orientation, family conference, voluntary work, flexible family care

$1 \quad{ }^{\star}$ Corresponding Author. Faculty of Education, University of Ljubljana, Slovenia; spela.razpotnik@pef.uni-lj.si.

2 Faculty of Education, University of Ljubljana, Slovenia.

3 Faculty of Education, University of Ljubljana, Slovenia.

4 Faculty of Education, University of Ljubljana, Slovenia. 


\title{
Podporno vstopanje v življenjski prostor družin
}

\author{
Špela Razpotnik, Nada Turnšek, Jana Rapuš Pavel in \\ Olga POLJŠAK ŠKRABAN
}

\& Skupina avtoric tega članka skupaj s širšo skupino sodelujočih študentk in študentov se od spomladi 2014 posveča raziskovanju ranljivih družin in njihove vpetosti v podporne vzgojno-izobraževalne sisteme. $\mathrm{V}$ prvi fazi smo raziskovale predvsem to, s katerimi izkušnjami in izzivi se te družne srečujejo ter kako jih razumejo in rešujejo. V nadaljevanju nas je zanimalo, katere oblike podpore so te družine deležne in kako se mreža podpornih ustanov odziva na potrebe teh družin oz. kakšna je kakovost njihovega vzajemnega sodelovanja. Posebej smo osvetlile obstoječe podporne ponudbe $\mathrm{z}$ vidikov vzgoje in izobraževanja ter socialnega varstva. Ugotovile smo, da v družinah in v njihovo podporo vključenih strokovnih službah obstaja velika stopnja nezadovoljstva v povezavi s sodelovanjem: družine se pogosto počutijo, kot da hodijo od vrat do vrat s svojimi težavami, ki ostajajo nenaslovljene, strokovne službe na drugi strani pa imajo v povezavi z ranljivimi družinami občutek, da njihovim težavam niso kos, da so nerešljive. Obe strani pogosto izražata tudi nezadovoljstvo nad neusklajenim pristopom pri delu z ranljivimi družinami, ki ga imajo različne strokovne službe, saj od družin pogosto pričakujejo zelo raznolike in pogosto tudi nezdružljive izide. Naša ključna ugotovitev je bila, da obstoječe podporne ponudbe potreb ranljivih družin pogosto ne dosežejo ter da bi bilo za dosego in naslovitev njihovih potreb nujno razviti prožnejše in usklajenejše oblike podpore, ki bi se odzivale na zaznane stiske ter izzive v njihovem vsakodnevnem življenju (Razpotnik, Turnšek, Rapuš Pavel in Poljšak Škraban, 2015).

$\mathrm{V}$ naslednji fazi raziskovanja, $\mathrm{v}$ akcijski raziskavi, o kateri poročamo na tem mestu, smo se usmerile v raziskovanje pa tudi podporo razvoju že obstoječih, porajajočih se alternativnih oblik podpore, katerih temeljne značilnosti so: prožnost, prisotnost v vsakodnevnem življenju družine, čim bolj sprotno odzivanje na potrebe, grajenje sodelujočega odnosa, dajanje prednosti dinamiki in potrebam družine pred formalnimi institucionalnimi/organizacijskimi zahtevami.

$\mathrm{V}$ članku utemeljujemo akcijski razvoj prožnejše in celostnejše oblike podpore družini, katere soiniciatorke smo raziskovalke same, njeni glavni nosilci pa prostovoljke in prostovoljci ter delavke in delavci 
NVO, ki vstopajo v vsakodnevno življenje družin. V članku opredeljujemo porajajoči se pristop prožne, $\mathrm{v}$ vsakodnevno življenje usmerjene podpore, ki jo udejanjajo in o njej poročajo predvsem prostovoljke in prostovoljci, predstavlja pa komplementarno dopolnitev konvencionalnim oblikam podpore družini, ki jo zastopajo in o njej poročajo predvsem predstavnice in predstavniki vzgojno-izobraževalnih in socialnovarstvenih organizacij.

Ključne besede: ranljive družine, podpora, socialna pedagogika, usmerjenost v življenjsko polje, družinska konferenca 


\section{Theoretical introduction}

\section{Lifeworld-oriented support}

One of the key principles in social pedagogy is its orientation towards the lifeworld (Mollenhauer, 1972); in an effort to deinstitutionalise pedagogical thought and practice, as well as to maintain its commitment to immediate practical tasks that stem from people's attempts to cope with life's difficulties, Mollenhauer introduced the concept of "lebeneswelt", which can be translated as "lifeworld". This paradigm was later developed by Thiersch (1992), who formulated the "bottom-up" approach. At its core, this means starting with the individual and, in line with the phenomenological tradition, their subjective perception of the reality in which they find themselves. It also entails utilising resources found in their environment. This paradigm is here joined by the discourse of resources. In contrast to the deficit mindset, which focuses on shortcomings, the discourse of resources dictates that the profession draw from what the individual, family or community do in fact possess, rather than defining their service users in advance as somehow deficient, problematic or disruptive. The "lifeworld-oriented social pedagogy" paradigm has already become established in Slovenia (Zorc-Maver, 2006). Particular attention is paid to the fact that professional work always runs the risk of either explicitly or implicitly (e.g., in the form of expectations concerning the desired outcome of the work) transferring its value system onto the service user. With a method that stipulates approaching the individual in his/her own environment and responding to his/her challenges here and now, this danger is at least somewhat reduced, as lifeworld-oriented approaches eliminate the institutional aspect and its implications of a specific value system, particular methods of solving problems and specific relationship hierarchies and perimeters (Razpotnik, 2014). Consequently, lifeworld-oriented approaches should, in this respect, have greater potential for battling the various socioeconomic frameworks of both the user and the employee, as entering the lifeworld of vulnerable families unsettles the hierarchical institutional distribution of power and destabilises preconceived notions that employees often have about service users. Lifeworld-oriented support should thus not foreground the need to meet the goals of specific institutions (whether educational, social welfare or another type), but of the individual and of the network that develops through professional intervention. Such support should be fuelled by the various areas of expertise demonstrated by people facing challenges in their daily lives. This is the source of another key premise of social pedagogy (as well as social work and other related professions): users 
themselves should be understood as experts, as they have the most experience when it comes to their own lives. Their experiential expertise should present a key point of orientation for professionals entering their lifeworld, whose role is often merely to bolster the individual's pre-existing endeavours and resources in his/her lifeworld (ibid.). One of the paradigm shifts triggered by the lifeworld-oriented approach and the opening up and democratisation of conventional institutions is the introduction of voluntary work as an intermediate structure. In education and social welfare, the introduction of voluntary work was designed to reshape institutions and respond to areas in which institutions were ineffective (Mikuš-Kos, 1979; Stritih, 1995). Therefore, voluntary work was not only an implicit criticism of what institutions provided, but also a way to implement changes. Volunteer projects have at least partly affected the relationships in institutions (Flaker, 2012). Such projects involve the cooperation and participation of professionals, researchers and the student population with socially devalued groups of people, working towards reducing stigma and creating new, less stigmatising identities.

\section{Drawing on family resources and family empowerment}

When it comes to utilising the family's strengths, and even its vulnerabilities, it is important to keep in mind the individual family's specific socioeconomic situation and developmental priorities (Walsh, 2016). One must always remember that informal social support can be understood as a "central helping system" of a family (Canavan, Pinkerton and Dolan, 2006).

A comprehensive approach to working with vulnerable families includes informal support for the family and consideration of its needs as a whole, as well as the needs of each individual member, both in terms of programme policy and available assistance programmes. It also includes the participation of family members in planning and decision-making processes. The paradigm of co-creating processes in working with families also emphasises building on empowerment and the strength perspective, enabling the users' participation in the solutions they need and can realise (Čačinovič Vogrinčič, 2016).

The following forms of working with families, on which our research draws, are relevant in this context: family group conferencing, family care planning and families leading planning (Morris, Burford and Barnes, 2009). What all three of these approaches have in common is that they give a central role to family members both in care planning and in making important decisions. The active inclusion of the family has the following characteristics: a broad definition of the notion of family; planning changes headed by family members; and 
decision-making with a professional who is first and foremost a coordinator and moderator of resources and services, and who fulfils a formal role in accordance with regulations and stipulations, if necessary (ibid.).

Chaffin et al. (2001, in Sousa, 2005) conducted a study reviewing programmes for vulnerable families in crisis who were included in various community care and support programmes. The results show that such approaches respond to concrete needs in the lives of families and their members, and are more effective than approaches primarily targeted at developmental needs and parenting support. The authors explain that a comprehensive approach requires the consideration of various stress factors - factors of poverty and the aetiology of neglect - that should be taken into account when determining care planning. Closeness, reciprocity and durability are also considered important qualities of support (Canavan, Pinkerton \& Dolan, 2006).

Study results (Sousa, 2005) show that the active involvement of families contributes to a significantly higher level of active participation in families who are otherwise isolated from social welfare programmes. The involvement of families in services planning initially encounters obstacles and resistance on the part of professionals, but over a longer period such involvement yields good results and leads the professionals to alter their views.

In the opinion of some experts, the comprehensive approach to support and cooperation is established mainly in preventive work with families, where problems are usually not yet extreme (Doolan, 2007). In Slovenia, assisting families at home within the framework of social welfare is a fairly underdeveloped area, a fact that we have addressed through the (action) research. Important theoretical input is, however, available regarding a holistic and systemic approach to families based in their lifeworld, such as that of Bouwkamp, Bouwkamp (2014).

\section{Case conferences and family conferences}

Our research includes the case conference method, which centres on a particular aspect or problem, and takes the form of an organised meeting of everyone involved in the vulnerable families study, with the purpose of presenting findings, comparing professional opinions, perspectives and approaches, co-creating the conditions for team-based methods, and encouraging coordination and compatibility in order to find more flexible and comprehensive responses to the challenges and needs of the families.

The main principle of family conferences is to engage families as systems in making decisions on social and general protection and welfare. By 
introducing this method, we prioritise the family's power and the practice of cooperation, rather than the usual practices of social welfare (Ney, Stoltz \& Maloney, 2011). Another important aspect of this approach is the "principle of family empowerment and participation, which is juxtaposed against conventional child welfare practices that focus on the rescue and protection of children" (ibid.). Merkel-Holguin (2004, p. 155) argues that family group conferencing has democratising potential to promote "the sharing of power for decision making between family, kin, professionals, state and community, while balancing responsibility and accountability among these groups". The findings of Merkel-Holguin's study (which is comparable to ours) show how legalistic and formalised discourse creates a power imbalance, putting family members in a disadvantageous position. Democratic discourse, based on empowering families, is able to diminish this, even though the inherent values of both approaches (family-based and traditional) remain incompatible with each other. This indicates the transformative nature of approaches such as family group conferencing, which can be used to achieve social justice, a particularly pressing concern in the current neoliberal system.

\section{Participatory action research (PAR) with the vulnerable family}

At this point, we briefly introduce participatory action research (PAR), which forms the background of the present article, in which we focus on one specific case. The aim of the participatory action research was to develop and implement the model of family-based, flexible and lifeworld-oriented family support. By definition, PAR is an empowering process that strives to create situations in which participants can increase their sense of control, their involvement in decision-making, and their critical awareness (Zimmerman, 2000). Kemmis and McTaggart (2005) revealed that PAR can also transform the practitioner's knowledge and practice; the perspectives of the practitioner may help to improve conditions of life and work in particular local settings.

Our research was predominantly conducted in 2014 and 2015 and developed in various phases. First, communication was established with individual participants and families, as well as with formal and informal family support networks, and our research objectives were presented to them. The research instrument was prepared and tested, and key content points were defined and formulated. This was followed by a period of data collection. Some responses regarding how a participant viewed the family situation and his/her own embeddedness in it were given in writing, while others emerged in conversation or through action. Both types of response were given by the volunteers. A group 
conversation was conducted with the employees of the NGO involved and an in-depth conversation was carried out with the parents of the family. Furthermore, anecdotal records from family visits or common events connected with the family were also collected. A case conference was then convened and a family conference was organised.

The participatory action research was monitored through anecdotal notes, minutes and other documents. In accordance with the principles of qualitative research (e.g. Creswell, 2014), we worked towards painting a complex, holistic picture; we analysed texts, absorbed the acquired information and conducted the study in a "natural environment", predominantly within the family itself or in directly related contexts. Comparable research (Ney, Stoltz \& Maloney, 2011) points out that such analysis requires a sharp eye for the articulation of both contradiction and complexity.

At the case conference, we examined the potential for bringing together all of the participants involved in supporting the family, with the family itself present and at the forefront. At the family conference, we particularly wanted to discuss the research process with the family, as well as their overall experience of participation.

Due to the fact that we focused on one specific family (A), it is necessary to present this family at least to some degree; however, the family is intentionally not presented in more detail in order to protect its privacy. The family consists of the parents and a larger number of children. The parents have been unemployed for a prolonged period of time, and most of the children are at different levels in various educational institutions. The family is socioeconomically underprivileged, at risk of eviction, and has in the past been threatened with eviction and the removal of children. The NGO and our volunteer initiative, on which the action part of the research is based, have been working with the family since the beginning of 2014. Considering the large number of volunteers involved in the family's care (by way of flexible volunteer care), we can say that the frequency of contact with the family is constant and relatively high; however, it is not structured, organised or exactly predictable, particularly because it is volunteer-based and because the participation and its format are being simultaneously established and developed.

According to the action development of flexible forms of support, we describe two practical frameworks of the present research. One is the model of volunteer-based family support, which emerged in parallel with our research as its action component. The other is the model of housing support provided by the NGO, which represents a semi-formal framework of the described volunteerbased family support. Both practices represent the foundation and framework 
for understanding the next steps in our research, and are therefore described further below. It should also be said that the process of establishing a flexible form of vulnerable family care continues as this article is being written.

\section{The model of volunteer-based family support}

We began these activities in 2014. Since then, a group of student volunteers and employees of the Faculty of Education have been continually visiting families who are experiencing social exclusion and who have expressed a desire to work with us. It is predominantly the students who are the regular visitors and companions (individual volunteers) to individual children. Our initial connection with the family who form the basis of the present study was an NGO that had begun offering assistance to the family and found that additional support could contribute to more effectively resolving the family's challenges, which at the time had been accumulating. We approached the family with an offer of volunteer-based support for the children and the family in their home.

The family is visited in their home, while individual children who have been placed in educational institutions and associated residential care facilities, or who attend kindergarten, are also regularly visited. Some volunteers focus on working with a particular child, whom they accompany regularly, while others focus more on contact with the family as a whole. Most volunteers find a balance between the two. The following quotation outlines both aspects - entering the educational institutions and the family - and the dynamics between the two:

And now, when we only visit the family, we are more a part of the family, whereas before we represented more kind of outside workers, even to the parents. That's my feeling. But I can't definitively say which I prefer. I think going to school is great, because things are more stable there and you can focus more on one child. But in the family, the fact that you can intervene on the spot in a chaotic situation, or have the opportunity to observe and to contribute in some way, speaks in favour of working in the family. It's very valuable, but sometimes difficult. The first [school visitation] is easier, and the second [family visitation] can be richer, but it's also more difficult. $\left(V_{1}\right)^{5}$

Individual volunteers decide to use a variety of activities, which fall within the scope of socialising, playing, facilitating new experiences, providing upbringing support, help in meeting formal requirements, learning, and even participating in daily activities (preparing meals, brushing teeth). We sporadically

5 The abbreviations V, PW, GO and NGO refer to volunteers, professional workers, governmental organisations, and non-governmental organisations. 
organise group events for the family and the group of volunteers. The latter regularly gather for intervision sessions, at which they exchange information about current activities, discuss dilemmas, and share their vision and ideas for future work. Due to the fact that it is currently not institutionalised, the nature of this work also means finding a balance between the formal and the informal. This form of working has been initiated in several families, but has taken place continuously and intensively throughout all of these years within only one family. The family conference that the article refers to was organised in an informal setting, while the case conference took place in an institutional setting in order to encourage a collective attempt to resolve a particular issue.

\section{The model of housing support conducted by the NGO}

The non-governmental organisation began to develop housing support in 2008, and has since been evolving and improving this support in reference to recognised needs. This means expanding to new, specific populations (single individuals, families and people with complex needs). Housing exclusion is usually a consequence of accumulated difficulties or exclusion from various areas of life. Support in maintaining housing means comprehensive and lifeworld-oriented support, the goal of which is not only preventing eviction but also improving the quality of life in all areas that are significant to either the individual or the family. The family on which our study is based was also included in the housing support programme led by the NGO.

\section{Objectives and research questions}

In this article, we mainly focus on a presentation of convergence and divergence in definitions of conventional support actors, on the one hand, and volunteers, on the other. On this basis, we construct the content of the flexible support that is conducted and developed through participatory action research.

The research questions are as follows:

- How do participants in the family support network view the individual aspects of the support? What do they view as the resources, and what do they see as the main challenges? Throughout, emphasis is placed on comparing the flexible approach, grounded in participatory action research, with conventional methods of support.

- To what degree do the views of the participants provide support in agreement, and in which areas do their definitions and approaches differ?

- Which forms of vulnerable family support would more effectively address 
the family's needs and steer the support spiral in a positive direction?

- How can flexible forms of support be developed through time?

\section{Sampling, methods and data collection}

Our findings are based on a study involving approximately 24 people. In addition to family members, the participants included five volunteers, four NGO workers and eight GO workers.

The methods used for data collection were: observation with participation, collecting miscellanea (various anecdotal records, journals, reports and minutes of meetings, intervision conferences), writing reports, and conducting semi-structured and open individual and group interviews. The data gathering tools were:

- five individual semi-structured interviews with volunteers (a list of open questions served as a basis for reflecting on work with the family);

- the transcript of a group conversation with the volunteers and the employees of the NGO (based on the topics gathered via the written interviews);

- the transcript of semi-structured interviews with four professionals from various state organisations offering family support (mainly in the educational context);

- the transcript of an interview with the parents;

- the minutes of the case conference;

- the minutes of the family conference; and

- miscellanea (various anecdotal records, journals, reports and minutes of meetings, intervision sessions, etc.).

The results and conclusions are mainly based on the quotations of volunteers, followed by workers in the NGO, as their answers were more comprehensive in comparison to some other sources (e.g., workers in the traditional organisation of support).

Most of the documents included in the analysis were conversation transcriptions or written responses to open questions. The volunteers' anecdotal notes and various minutes were also included. The key themes were identified using the iterative approach (Ney, Stoltz \& Maloney, 2011), comprising consecutive phases of global reading of the material, preliminary identification of the main themes, and repeated delving into the literature, which informed subsequent readings and clarified key themes. This was followed by identifying a number of paragraphs that illustrate the key themes. A combination of the 
inductive and the deductive approach was used. The key themes identified were prominent in the conversations and reports of the participants offering flexible care, on the one hand, and of the representatives of conventional, governmental institutions, on the other. As a result, one of the key focal points of the analysis was the comparison of both sides, mainly with the intention of defining the outlines of the developing flexible and lifeworld-oriented form of family support. Elements of critical discourse analysis (Van Dijk, 1993) were also used in the analysis. This approach assisted us in understanding the meaning shaping the speech, discourse and practices of the individual participants. Based on all of the above, we formulated several key contradictions - or, to use Freirean terminology (Freire, 1972), generative themes - that are expressed in the analysis of both the conventional and the flexible approach.

\section{Findings}

What follows is an exposition of the key themes that emerged through an analysis of the documents collected in the process of participatory action research, and according to the research questions set in the present article.

\section{Between structure and flexibility}

The volunteers entering the family describe this sort of support as unstructured and inconsistent, noting inconsistency in reporting, unreflected objectives, and support frameworks that are being developed and interpreted at the same time. At first glance, this is in contrast with conventional, formalised and bureaucratic forms of state care, whether in social service centres or within the context of education. The volunteers describe their approaches, as well as their role, as dispersed and context-specific. Their role is described in the following range: a volunteer who visits the family; someone who alleviates the family's burdens; someone who offers parents support in childrearing, teaches them about upbringing practices and reduces their burdens; someone who serves as an advocate for the family and protects them in relation to the other institutions involved, or even with regard to public opinion:

$M y$ visits to Family $A$. There's a whole range: from a quick cup of coffee to walks in the woods with another volunteer, the cinema, a mountain hike. Then there are the trips we take together. I do a lot of different things. I decide spontaneously. Maybe the problem is that I'm not being very consistent. For example, it's not a case of coming over regularly every Tuesday, but I definitely always call first, about a day in advance. (V2) 
Although the volunteers point out that the global objectives of working with the family are unreflected, it is possible to detect a high level of selfreflection in the conversations with them (in terms of how they see and contemplate their own work). This is certainly galvanised by the fact that the model is developing, that the group is expected to have reflected on what they report about their visits, and that the intervision sessions enable the group to discuss dilemmas, report on visits and exchange their opinions.

One of the aspects brought to the forefront due to the model's flexibility is that the volunteers see a need to strive for consistency:

I decide based on the needs I see are there, based on how many children are at home and what the dynamics and atmosphere are like. One of the children needs a bit more attention, or if the home is untidy and I see that it'd suit the mother if the children went away for a while so she could tidy the place up a bit ... the week before last, because I was there a lot, I tried to divide my attention as evenly as possible, so everyone gets at least some, and so that I stick to any arrangements. If I've made an arrangement: "Right, we're going on a trip the day after tomorrow," I'll stick to it. I think this is essential, so they feel that I am consistent." (V2)

When the volunteers describe meeting with the children individually, they often mention socialising, relaxing, fun and learning. Another important aspect in this case is adjusting and responding to the needs perceived at that moment:

There's a lot of adjustment on my side, more and more acknowledgement, listening and making compromises on his [the child's] side. (V5)

It would appear that this form of work is often incompatible with pursuing objectives. This is because the situation in the family, reflected also by each member, is extremely changeable, fragile and uncertain. It seems to require a larger measure of flexibility and ingenuity, as well as a willingness to abandon any predetermined goals for a specific meeting and to deal with what is possible in a given situation:

But it seems that again and again I struggle with anything I set as a goal because something completely new happens, and then these goals become a bit less important. So it seems to me that you're always looking for some ... that you're always finding a balance. $\left(V_{5}\right)$

The key axis around which the opposition between structure, which is recognised as necessary in working with the family, and flexibility, as the basic principle of the model we describe, continues to revolve, is exactly that: 
constantly finding a balance between both aspects. This requires the volunteer to show autonomy, professional judgement and an ability to reflect; the opportunity to discuss this with the group is a big advantage. The need is expressed for a clearer structure of the entire family care model enterprise, which in these first few years has been rather vague, changing and uncertain. The most frequently emphasised drawback of the developing model (its lack of structure and links to formalised objectives) is at the same time its significant advantage: by being one of the aspects that sets it apart from existing conventional forms of support, it brings the support closer to the family and makes it more accessible, and, finally, enables it to endure despite changes.

Despite expressing dissatisfaction with conventional, established forms of vulnerable family care (demonstrated, for example, by the following quote) and striving to surmount the subordination of family dynamics to pre-established formalised objectives, there was also significant awareness of the difficulty of finding the correct course of action in complex family situations, and of the heavy burden of responsibility carried by the person making important decisions:

No individual plan can be written so that it would encompass the user's existing needs in their entirety. It can result in a simplified understanding of the user, reflecting a predetermined collection of bullet points and reducing the complexity and uniqueness of the individual to a set of sociological or psychological constructs. $\left(V_{3}\right)$

I often don't know what would be best for their children, and I'm glad I'm not the one who has to make the decisions. (V2)

An important subtheme is the volunteers' waiving of their own expectations and their increased competence in doing so. This is linked to the aspect of blending into family life and having increased knowledge of the context in which the family exists, as well as to the ability to make a subtle distinction regarding which family tasks and themes should have priority:

I was thinking that I also have this huge dilemma when it comes to swearing. We insist so strongly that swearing is bad and that we won't stand for it [...]. I feel like you have the assumption that when you raise children, you try to raise them not to swear, even though most adults will still swear. But if you look at Family A, the probability is so high that I really don't know whether it's worth starting a conflict just because I feel like my principles have been a bit morally violated if an eight-year-old swears in front of me. Things like that. There is a lot of inner struggle about what is really important from their perspective... (V1) 


\section{Resource-based versus deficit-based approaches}

The volunteers noticed and reported how their role in the family changed over time, and how various aspects of family life also changed:

I'd say that we've gone from having the status of a guest, someone who comes over and is served coffee, to being sort of a friend, or let's say acquaintance, who comes over and does some activities, primarily with the children, but afterwards they'll say: "Sit down for a while." (V3)

One of the volunteers presents his role in the family in terms of a deepening relationship, and points out the nature of certain relationships:

From spontaneous socialising, getting to know each other and talking, the relationship has progressed in the direction of more frequent socialising and a more personal connection with certain family members. (V4)

Representatives of the NGO also point out that a continual presence in the family is of central importance when it comes to understanding the complexities of family life and the dynamics of individual relationships. They reveal how entering the family can change the focus from a deficit-based approach to a different understanding, one that is able to encompass complexity:

If you look at it from the outside, you think "oh no", but when you visit the family, you see that there is a lot of love between these people. For example, I've been touched by the relationship between children and mothers, regardless of what was happening. Most of these mothers have developed a strong relationship with their children, a sort of bond, irrespective of the difficult circumstances they live in. And you don't see that if you don't go and make contact, if you're not present. (PW of $N G O_{1}$ )

One of our participants stresses the aspect of variability, the family's ability to create new situations, and also emphasises the non-linearity of the process of entering the family. On the one hand, this is due to new and unpredictable circumstances, but, on the other hand, it is a result of the inconsistency of the visits themselves. She also describes experiencing a shift in roles, forming a telling spectrum on the proximity-distance continuum. We can also talk about shifts on the formal-informal spectrum:

You start tentatively delving into it a little again, and then you get used to it again, so I felt that we were getting back to being friends, and then acquaintances, and then friends again and then family again. It fluctuates. It depends very much on how many of us come over and how we participate. 
Maybe it's also the fact that we go to school [to accompany individual children] that has diminished some of the family feeling. (V1)

One participant describes an increasing feeling of her own authority over time when it comes to guiding parents on issues of upbringing:

I see that lately, now that I know the family better, the atmosphere is more relaxed and I'm comfortable with performing with a little more authority. I'm not so careful about treading on their toes in terms of parental rights, I already have a confidence that comes from feeling that what I do is okay. I've become more, let's say, confident. (V2)

The volunteers also report the increasingly active role of the parents in the children's upbringing, observing that they are managing better and that over time they have successfully begun voicing their opinions or delegating tasks more confidently; in short, they are expressing their needs. Part of the process is perceiving positive changes, from the subtle to the more visible; this inspires the volunteers and gives them encouragement in their work. While the observations about gradual changes are phrased delicately because they are not based on any measurable indicators, they still add a note of optimism to the volunteers' reports.

The volunteers attribute an increased level of initiative to family members, and recognise that they are competent and trustworthy agents in their own lives. Concrete changes were detected particularly in terms of the children's upbringing; for example, in the parents' clearly expressing their wishes and demands:

I get the impression that the parents are slowly becoming susceptible to [our] endeavours and are a bit clearer and more resolute in their upbringing practices with the children. (V2)

Further changes were noted in terms of the children's greater openness over time, and their willingness to express their own wishes and expectations:

Some of the children are much more open and say a lot more; they are more proactive, which was also observed by childcare workers and pedagogues in residential care. The parents began to ask questions and talk about methods of upbringing, the mother emerged from the background, the dining table was moved away from the television, some childcare workers started thinking about the suitability of the existing lines of specialised schooling for the children, etc. It's difficult to say what the positive effects of our participation have been, but things are changing. ( $\left.V_{3}\right)$ 
A comparison of the reports of the volunteers and the NGO, on the one hand, and those made by representatives of conventional, state programmes or services, on the other, shows that the former note many more strengths and resources, and much more progress. This is particularly noticeable in the attitude towards the parents. There is a tendency for conventional services to focus on deficits and be more critical towards the parents. For example:

I think the mother needs someone to be with her to see where she isn't coping, where she isn't organised, to prepare a plan for her, something that she could rely on. ( $\mathrm{PW}$ of $\mathrm{NGO}_{3}$ )

In contrast, the volunteers find that progress has been made both with the parents and the children:

I see the parents trying to do the best they can ... They participate, they listen to advice, they persevere and invite [us] into the family, to work together. $\left(V_{3}\right)$

The existing conventional services often operate by stepping in when there are problems in the family, but during "quiet periods" they usually do not see the need to visit the family, which in itself directs the focus onto deficits. On the other hand, a more or less continual presence enables volunteers or professionals to observe the family in very different situations, from entirely ordinary daily life, to particularly enjoyable occasions (e.g., celebrations) or even more difficult situations (when problems occur). Being present in the family means being in an environment where the family are in command, where they feel confident. Unlike the environments to which they are invited by the various services, families have more power in their own environment, starting with the power to invite someone into their home. The volunteers are aware of their role as guests, which they adhere to by always calling the family before visiting to make sure the timing is suitable. With the specific family of the present study, it is worth noting that, with the exception of one example at the very beginning of our work together when they cancelled a planned arrangement, they have always openly accepted visits from the volunteers, as well as accepting all of the other suggested group activities. Either parent will typically end a telephone conversation with:

You just come over, we're home all day.

Focusing on the family's resources and strengths is related to the theme of trust, a significant theme for the volunteers as well as for the NGO and the conventional organisations. The quotation below relates the feeling that the children's 
upbringing is the area where the parents need the most support, while other areas (taking care of the finances and the home) are more under their control. However, even here the presence of volunteers can have an unburdening effect:

I trust both parents, that they can handle things if we give them support with the children's upbringing. This is the area where they are the most powerless. This is where they don't have control. In terms of the finances, they aren't perfect, but they can manage ... that's the feeling I get. That they need some of the load to be taken off their shoulders. Sometimes they will tell us to take the children somewhere because they have to take care of something. Or they say, take them there so we can tidy up, so we can get something done. In that sense. ( $\left.V_{2}\right)$

The theme of trust is significantly expressed, particularly by the NGO, in another respect: when it comes to coordinating, assessing and determining how to intervene in the family (sometimes in the interest of child safety) in a way that is non-invasive, sensitive and appropriate:

It seems to me that you have to tread very carefully the whole time because trust can very quickly be lost. These are the kinds of dilemmas we face, being split between family members, I don't know, the family, the child, the spouses, and then these outside institutions ... (PW of NGO 2)

All of the contributors attach great importance to trust, and they draw professional encouragement from the fact that it is an ongoing process and that they see progress. This is much easier to notice if you are close to the family, if you share various experiences with them and if you have an opportunity to see them in their own environment, one they know and are in control of. This makes it easier to identify and support those resources that already exist in the family's environment and utilise them in a professional capacity.

\section{Flexible care for families within their living environment}

From conversations with the parents, family conferences and analysis of anecdotal records, it is clear that the family expresses satisfaction with the developing form of flexible care in their everyday lives. This is expressed both on a declarative level as well as through behaviour, with the family showing a great deal of trust and initiative, making suggestions and particularly by always keeping their door open to the volunteers. In particular, the family (the parents) appreciate the non-invasive nature of this type of support, because, as a rule, the volunteers follow the parents' initiative, ask for permission and do not 
introduce changes without first obtaining the parents' consent. Furthermore, they are flexible and, because their involvement is voluntary in nature, they can adapt to the current needs of the family.

A common thread in the volunteers' responses is that there is a lot of deliberation on how to go about their work, what kind of goals they are pursuing as a group, whether they are acting correctly, and how they could optimise their work to be more in tune with the needs of the family. They also note that they have become more assertive in their attempts to address various subjects with the family over time. A key theme that they scrutinise is flexibility: the advantages it offers, as well as its limitations. Another important aspect is that this developing form of volunteer care is on the border between the formal and the informal, which gives rise to many questions in terms of establishing boundaries, reciprocity and so on.

The care and support offered by the non-governmental organisation is also flexible, yet remains more formalised than the developing model described above. One similarity is its dialogue-based approach to the work, which follows the dialectics of comprehensive care and, at the same time, individualised treatment. An additional contradiction inherent in both approaches is the dialectics of being oriented entirely towards the practical aspects of people's lives and needs, while at the same time taking into account the deeper psychosocial needs of individuals and attempting to respond to them.

The governmental organisations that work with the family in one way or another (the children take part in their programmes) are noticeably more sparing in their answers concerning the family than the volunteers or NGO workers. This can be attributed to the interaction of various factors: the research group had less access to these individuals and they possibly have less involvement with the particular family. Furthermore, the research is set up in such a way that there is significantly more focus on researching the developing a flexible form of family support. Nevertheless, we can point out some key and common themes based on the answers of the representatives of conventional institutions, and on our interaction with them. The responses cited below are those that occur more frequently and can be considered more relevant.

GO workers report that, before the child's admission, they had no information about the child or the family, something that would have made their work easier, more targeted and more effective. They also link this with poor interconnections and lack of trust between organisations, which is another important key theme in their responses:

In my estimation, there is not enough cooperation and connection with other services. Until now, I can only recall being in contact once with another 
organisation that was also working with the family. As a professional, I'd like there to be more interconnection, more exchange of ideas, dilemmas, experiences that individual services notice with this family. (PW of GO 1)

Another worker pointed out the fact that teams only meet when serious difficulties arise (not on a regular basis), and even then there are obstacles when it comes to sharing information. While data protection serves to protect the family, the question remains as to how far this is substantiated and at what point it becomes counterproductive. In certain cases, these security regulations can cripple any cooperation between organisations, which may result in urgent problems remaining unsolved and the failure to provide the necessary support. As an example, one of the workers says that, because she does not have the boy's paperwork, she does not know why the responsible authority is not working with him on speech development.

When experts in conventional services talk about the family, many things are based on assumptions rather than experience, because they either have no experience of home visits or such visits are very rare. They are aware of the fact that their perspective on the family is based only on suppositions, and they point this out on a number of occasions. They express the need and desire to be informed and more connected with the family, particularly because this family is very specific in its combination of various forms of vulnerability, as well as past experiences of exclusion and stigmatisation. The services representatives often mention a particular social welfare body that has a great deal of of jurisdiction when it comes to the family, but they express doubt as to whether this form of cooperation is sufficient for the family's needs:

They probably do what is urgent and don't go into too much detail, it's more superficial. They go and see them just so they can tick all of the boxes on their forms ... I have the feeling that we need something else, something more, which we can't offer them within the framework of social assistance systems in this country. The girls [her co-workers at the institution] here have been thinking that we need someone who is really with them, the way you visit them, but you can't place that kind of responsibility on volunteer and non-governmental organisations. (PW of GO 1)

The above quotation also addresses the commonly expressed theme of the family's needs, with the participants recognising significant potential in our developing form of flexible support in the family:

I value - and we've been talking about it here - the method you use, that you go into the battlefield, because it's really the most valuable and most 
effective, I think. We've also got a wealth of information from you that we otherwise wouldn't have. I don't know anything about anyone else working with the family. (PW of $G O$ 2)

The need to support the family in its lifeworld in a professional capacity is thus one of the key themes. The idea of what that support should be like is centred on its professionalisation:

We feel the lack of having someone who has worked with the family in the home. This is needed to complete the circle of assistance, because there is a gap here. ( $P W$ of $\mathrm{GO}_{3}$ )

This quote also indicates the theme of the perceived disparity between the world of institutions (kindergarten, school, etc.) and the home world. This is particularly noticeable in the demands of upbringing and the structure of daily life and routine, as well as in the supposed "cultural differences" between the two environments, i.e., different attitudes to gender roles, sexuality and alike. The professional workers feel that an intermediate, flexible form of family care in the home could bridge the gap between the home and the children's educational institutions.

This view addresses the polarity between two approaches: one that focuses on the importance and autonomy of the family environment irrespective of cultural differences with regard to the situation prevailing in educational institutions, and one that advocates the earliest possible inclusion of children from vulnerable families or underprivileged cultural environments in the education system in a compensatory role. Approaching families in their daily environment and recognising, acknowledging and respecting the family's reality as it is can build a bridge between the family world and the world of outside institutions, thus opening dialogue between them and reducing potential discord and misconception.

\section{Conclusions}

The crucial dimensions of flexible support for vulnerable families can be defined as: continuous awareness of the context, the use of variety and the flexibility of approaches, and developing new, innovative solutions that arise from dialogue between the various actors (the family and its support network). The challenges of the family can be addressed more comprehensively and promptly through flexible support, whereby support is based on experience and not assumptions. Due to its life-orientation, the support offered is not invasive; it can 
adapt to the current needs of the family more easily and provide the family with practical everyday support. Targeting family resources and weakening the deficit-based approach can be seen as one of the main benefits of flexible support in comparison to conventional family support (Sousa, 2008). In addition, we can define certain obstacles to the effective support for vulnerable families that lie within existing services/institutions: an approach that is oriented towards deficits and difficulties instead of towards the power and resources of the family; and the controlling and supervising role of institutions, which is incompatible with the supportive role they are mandated to offer. It should, however, be noted that the flexibility of the lifeworld-oriented approach, which can be seen as its greatest advantage, can also be seen as a limitation, as it lacks the structure and durability of conventional services.

One related topic, also highlighted in other relevant research, is the tension between the principle of family empowerment and participation, on the one hand, and the principles of conventional child welfare practices that focus on rescuing and protecting children, on the other. This tension, interpreted as "one of the most complex and sensitive aspects of social work practice" (Healy \& Darlington, 2009, in Ney, Stolz \& Maloney, 2011), can also be seen in our case.

Our example illustrates the opposition between the bureaucratic organisation of the conventional support system available to the family and the democratic system of family empowerment represented and bolstered by a flexible approach to supporting the family within its own environment. The thesis has been confirmed in conversation with the parents and by the viewpoints of the volunteers, as well as by both governmental and non-governmental support services. All of the participants from the various institutional frameworks recognise the benefit of support that is in close proximity to the family and has an opportunity to support its real-life situations.

The future development of support services for vulnerable families therefore lies in increased flexibility and intensified supportive entering the family. This can be conceived in at least two ways. The first is the strengthening and gradual professionalisation of the voluntary models of family support within the family environment, as presented in our research. The second involves transforming conventional services, making them more flexible and familycentred, and resolving the contradiction of their supervisory and support role.

Our research clearly shows the benefits of the mutual collaboration of everyone involved, of bringing different perspectives together through dialogue and leading them forwards in accordance with the main actor who should have the central role: the family that needs support (see also Rodrigues \& Sousa, 2008). The advantage of the conferencing approach (see Merkel-Holguin, 2004) 
that our research reveals is that case or family conferences are a suitable form of raising topics around families, of exercising democratic and non-hierarchical ways of collaboration. Conferences are not only a means of addressing problems, they can become a regular co-creative practice for family members and for the experts involved in the life of the family.

The main future challenge regarding this kind of practice lies in finding an ongoing balance between the formal and the informal, the structured and the spontaneous. Flexible support for vulnerable families certainly is a field that needs further professional and research attention.

\section{References}

Bouwkamp, R., \& Bouwkamp S. (2014). Blizu doma. Priročnik za delo z družinami [Near Home. Manual for working with famillies]. Ljubljana: Znanstvena založba FF; Pedagoška fakulteta; Inštitut za družinsko terapijo.

Canavan, N., Pinkerton, J., \& Dolan P. (2006). Family support as reflective practice. London: Jessica Kingsle Publishers.

Čačinovič Vogrinčič, G. (2016). Social work with families: The Theory and practice of Co-creating Processes of Support and Help. In N. Mešl, \& T. Kodele (2016). Co-Creating Processes of Help: Collaboration wih Families in the Community. Ljubljana: Faculty of Social Work.

Creswell, J. W. (2014). Research Design: Qualitative, Quantitative, and Mixed Methods Approaches. London: SAGE.

Doolan, M. (2007). Working towards and effective agency mandate for family group conferences. In C. Ashley, \& P. Nixon (Eds.), Family Group Conferences - Where Next? London: Family Rights Group. Flaker, V. (2012). Kratka zgodovina dezinstitucionalizacije v Sloveniji [Short History of Deinstitutionalisation in Slovenia]. Časopis za kritiko znanosti, domišljijo in novo antropologijo, 250, 13-30.

Freire, P. (1972). Pedagogy of the oppressed. Harmondsworth: Penguin Books. Kemmis, S., \& McTaggart, R. (2005). Participatoriy action research: Communicative Action the Public Sphere. In N. K. Denzin, \& Y. S. Lincoln (Eds.): The Sage handbook of qualitative research (3rd. ed. pp. 559-603). Thousand Oaks: Sage.

Merkel-Holguin, L. (2004). Sharing power with the people: Family group conferencing as a democratic experiment. Journal of Sociology and Social Welfare, 31(1), 155-173.

Mikuš-Kos, A. (1979). Nepoklicno prostovoljno preventivno in socialno terapevtsko delo $z$ otroki in mladino [Unprofessional, voluntary, preventive and socio therapeutically work with children and youth]. Ljubljana: Inštitut za sociologijo.

Mollenhauer, K. (1972). Theorien zum Erziehungsprocess [Theories within Education process].

Munich: Juventa.

Morris, K., Burford, G., \& Barnes, M. (2009). Family decision making: new spaces for participation 
and resistance. Policy Press: University Press Scholarship Online.

Ney, T., Stoltz, J. A., \& Maloney M. (2011). Voice, power and discourse: Experiences of participants in family group conferences in the context of child protection. Journal of Social Work, 13(2), 184-202.

Razpotnik, Š. (2014). Socialno v socialni pedagogiki [Social in social pedagogy]. Sodobna pedagogika, 65(3), 54-70.

Razpotnik, Š., Turnšek, N., Rapuš-Pavel, J., \& Poljšak-Škraban, O. (2015). Potrebe ranljivih družin in odzivi vzgojno-izobraževalnega sistema [The Needs of Vulnerable Families and the responses of Educational System]. In T. Devjak (Ed.), Vpliv družbenih sprememb na vzgojo in izobraževanje [The Impact of Social Changes for Education], (pp. 309-324). Ljubljana: Pedagoška fakulteta, Rodrigues, S., Sousa, L. (2008). Intervening in-between: controlling and/or collaborating?, In L. Sousa (Ed.), Strengthening Vulnerable Families (pp. 17-36). New York: Nova Science.

Sousa, L. (2005). Building on personal networks when intervening with multi-problem poor families. Journal of Social Work Practice 19(2), 163-179.

Sousa, L. (2008). Actions towards strengthening vulnerable families. In L. Sousa (Ed.), Strengthening Vulnerable Families (pp. 177-193). New York: Nova Science.

Stritih, B. (1995). Prostovoljno delo kot prostor, v katerem se oblikujejo generativne teme [Voluntary work as a space where generative themes generate]. Socialno delo, 34(1), 5-20.

Thiersch, H. (1992). Lebensweltorientierte Soziale Arbeit [Lifespace oriented Social Work]. Munich: Juventa.

Van Dijk, T. A. (1993). Principles of critical discourse analysis. Discourse \& Society, 4(2), 249-283.

Walsh, F. (2006). Normal Family Processes: Growing Diversity and Complexity. New York: The Guilford Press.

Zimerman, A. (2000). Empowerment theory psychological organisation and community levels of analysis. In J. Rappaport, \& E. Seidman (Eds.). Handbook of Community Psychology (pp 43-63). New York: Academic/Plenum.

Zorc-Maver, D. (2006). Socialna pedagogika v družbi negotovosti [Social Pedagogy in the Risk Society]. In M. Sande, B. Dekleva, A. Kobolt, Š. Razpotnik, \& D. Zorc-Maver (Eds.), Socialna pedagogika: izbrani koncepti stroke [Social Pedagogy: professional Concepts] (pp. 23-35). Ljubljana: Pedagoška fakulteta.

\section{Biographical note}

Špela RAzpotnik is Assistant Professor of social pedagogy at the department for Social Pedagogy at the Faculty of Education in Ljubljana. Her research and professional interest is focused on the field of minorities, human rights, youth at risk, gender inequality, migration and homelessness, field work, cultural animation, intercultural project development of innovative models of working with marginalised social groups. 
NADA TuRnšEK is Assistant Professor of sociology of education at the Department of Early Childhood Education at the Faculty of Education in Ljubljana. Her research interest include tackling social and cultural inequality trough early childhood education and care, democratisation of early childhood system and settings, as well as providing equal education opportunities and counteracting discrimination. In recent years she is involved in (action) research exploring the needs of vulnerable families with young children and searching for more comprehensive, flexible and interdisciplinary expert responses from within and outside the system of preschool education.

JANA RAPUš PAVEL is Assistant Professor on Department of Social Pedagogy, Faculty of Education, University of Ljubljana. She has participated in several action and qualitative research projects, which involved different vulnerable groups (unemployed youth, children with behaviour difficulties, vulnerable families). She is certified gestalt family psychotherapist. Her recent scientific projects are related to vulnerable families, specifically to analysis of cooperation of parents and professional services in the process of out-home-placement.

Olga PolJšak Škraban is Assistant Professor of developmental psychology at the Department of Education Studies and in the Department of Social Pedagogy at the Faculty of Education in Ljubljana. Her fields of research are the family and development in adolescence and adulthood, and collaboration with parents. Past few years she participates in researching vulnerable families and developing new models of working with them. 